\title{
CUIDADO, PEDALAR PODE DAR CADEIA!
}

Coluna publicada em 5.5.2015: <http://www.conjur.com.br/2015-mai-05/ contas-vista-cuidado-pedalar-dar-cadeia $>$

Nestes últimos dias as "pedaladas fiscais" voltaram às manchetes dos principais meios de comunicação do país, tendo em vista a publicação de acórdão do Tribunal de Contas da União ${ }^{1}$ (TCU), trazendo novamente a Lei de Responsabilidade Fiscal, que acaba de completar 15 anos de sua publicação, para o centro das atenções. $^{2}$

O tema assumiu destaque, especialmente por reacender o debate sobre a possibilidade de impeachment. E uma análise cuidadosa permite constatar estar havendo imprecisões e má compreensão com relação a um aspecto ainda muito pouco estudado no âmbito do Direito Financeiro, que é o seu caráter sancionatório e a responsabilidade financeira dos gestores públicos. ${ }^{3}$

No caso das "pedaladas fiscais", assunto já abordado em coluna anterior, o TCU, após inspeção iniciada a partir de representação do Ministério Público de Contas, constatou a violação a preceitos da legislação financeira por várias autoridades governamentais de alto escalão, entre as quais o Ministro da Fazenda, o Presidente do Banco Central, o Secretário do Tesouro Nacional, Presidentes dos

1 Acórdão 825/2015 TCU - Plenário, rel. Min. José Múcio Monteiro, j. 15.4.2015.

2 Os feiticeiros em apuros. Revista Veja, ed. 2422, de 22 de abril de 2015; TCU diz que governo cometeu crime de responsabilidade fiscal, em 15 de abril de 2015 e TCU põe governo contra a parede, 19 de abril de 2015, ambas no O Estado de S.Paulo; Tribunal de Contas da União aponta crime nas manobras fiscais, em 15 de abril de 2015, na Folha de S.Paulo, entre muitas outras.

3 Neste assunto, cabe destacar a obra Responsabilidade financeira - uma teoria sobre a responsabilidade no âmbito dos tribunais de contas, de Emerson Cesar da Silva Gomes (Porto Alegre: Núria Fabris, 2012). 
principais bancos estatais e vários outros Ministros de Estado, em especial daqueles que versam sobre as operaçóes de crédito do poder público.

Apurou-se que os bancos estatais efetivaram vários pagamentos, como bolsa-família, seguro-desemprego e benefícios previdenciários sem que tivessem recebido os respectivos repasses dos recursos pelo Tesouro, em um "adiantamento", verdadeiro uso de "cheque especial" por parte do Governo, ${ }^{4}$ nisto consistindo as operaçōes que foram apelidadas de "pedaladas fiscais".

Os "ciclistas das finanças públicas" procuraram, assim, indevidamente, divulgar resultados fiscais melhores do que a realidade apresentava, por meio de uma "contabilidade criativa" que "maquiou" as contas públicas.

Neste ponto, vale a pena citar as palavras do Ministro-Relator José Múcio Monteiro: ${ }^{5}$

Tomemos por exemplo os programas do Governo operados pela Caixa. O Tesouro deixa de repassar os valores a serem pagos, mas a instituição financeira efetua os pagamentos aos beneficiários, passando a ser credora da União pelo valor correspondente. Como esse passivo do Tesouro junto à Caixa não está abrangido nas estatísticas de endividamento utilizadas pelo Bacen, os adiantamentos feitos pelo banco também não são captados no resultado primário apurado pela autarquia. Ou seja, muito embora os benefícios estejam sendo pagos, por intermédio da Caixa, não são contabilizados como despesas no resultado primário da União, por meio da elevação da dívida do Tesouro junto à instituição financeira. Assim, somente no mês em que a União paga à Caixa pelos adiantamentos feitos é que os dispêndios são computados nas estatísticas oficiais, quando o correto é a contabilização da despesa e do consequente endividamento da União no mês do pagamento efetuado pela Caixa.

Essas operações, consoante defende o TCU, são verdadeiras operações de crédito, e realizadas pela União com instituições financeiras por ela controladas, em afronta ao artigo 36 da Lei de Responsabilidade Fiscal. Violaram também, como constatado pela inspeção realizada pelo TCU, os artigos 32 , I e $\$ 1^{\circ}$, e 38, IV, b, da LRF, uma vez que não houve prévia autorização da lei orçamentária e consistiu em uma ARO (operação de crédito por antecipação de receita orçamentária) no último ano de mandato. ${ }^{6}$

4 Conforme menciona o citado acórdão do TCU, p. 85, item 23, p. 3 do voto do rel. Min. José Múcio Monteiro.

5 Acórdão TCU 825/2015, p. 87, voto do Min. José Múcio Monteiro, \$ 37, p. 5.

6 Acórdão TCU 825/2015, p. 87, voto do Min. José Múcio Monteiro, \$ 33, p. 86. 
Violações às regras e princípios de direito financeiro podem gerar diversos tipos de respostas jurídicas que não se limitam ao impeachment do Chefe do Executivo. Há sanções institucionais, que incidem sobre o ente federado violador, e sanções pessoais em diferentes esferas de responsabilização, tema que é oportuno tratar agora, na tentativa de melhor compreendê-lo.

No caso do artigo 36 da LRF, há previsão de sanções institucionais, como a vedação do recebimento de transferências voluntárias (LRF, art. $25, \S 1^{\circ}, c$ ), o que, para a União, mostra-se de pouca eficácia, uma vez que é essencialmente um ente da federação que repassa referidas transferências, e não um beneficiário delas. Um ponto a ser corrigido na LRF, pois deixa pouca margem à aplicação de sanções quando o ente federado que comete a infração é a União.

Mas a própria LRF, em seu artigo 73, remete a outros diplomas legais as possibilidades de punições para as infraçōes a seus dispositivos, e aí podem ser encontradas sançôes de outras naturezas, inclusive pessoais, aplicáveis aos atos praticados contrariando dispositivos da LRF.

É caso, por exemplo, dos crimes contra as finanças públicas, pouco conhecidos até mesmo pelos estudiosos e operadores do Direito Penal, cuja aplicação praticamente não se vê na prática. Estão previstos no art. 359 do Código Penal, 7 com redação dada pela Lei 10.028, de 2000, com oito tipos penais (arts. 359-A a 359$\mathrm{H}$ ), entre os quais está o crime de contratação de operação de crédito, que consiste em "ordenar, autorizar ou realizar operação de crédito, interno ou externo, sem prévia autorização legislativa" (Código Penal, art. 359-A), cuja pena prevista é de um a dois anos de reclusão. São também puníveis na esfera penal os crimes assunção de obrigação no último ano do mandato ou legislatura ("Ordenar ou autorizar a assunção de obrigação, nos dois últimos quadrimestres do último ano do mandato ou legislatura, cuja despesa não possa ser paga no mesmo exercício financeiro ou, caso reste parcela a ser paga no exercício seguinte, que não tenha contrapartida suficiente de disponibilidade de caixa” - Código Penal, art. 359-C, cuja pena prevista é de reclusão, de um a quatro anos) e ordenação de despesa não autorizada ("Ordenar despesa não autorizada por lei” - Código Penal, art. 359-D, cuja pena prevista é de reclusão, de um a quatro anos).

Outra situação são os atos de improbidade administrativa, previstos e punidos nos termos da Lei 8.429, de 1992.

Neste caso, há descrição de condutas ilícitas como os atos de improbidade administrativa que causam prejuizo ao Erário, tais como "realizar operação financeira

Sendo o último artigo que descreve tipos penais no Código Penal. 
sem observância das normas legais e regulamentares ou aceitar garantia insuficiente ou inidônea" (art. 10, VI) e "ordenar ou permitir a realização de despesas não autorizadas em lei ou regulamento" (art. 10, IX).

Para essas hipóteses, prevê-se, independentemente das sanções penais, civis e administrativas, o ressarcimento integral do dano, perda dos bens ou valores acrescidos ilicitamente ao patrimônio, perda da função pública, suspensão dos direitos políticos de cinco a oito anos, pagamento de multa civil de até duas vezes o valor do dano e proibição de contratar com o Poder Público ou receber benefícios ou incentivos fiscais ou creditícios, direta ou indiretamente, ainda que por intermédio de pessoa jurídica da qual seja sócio majoritário, pelo prazo de cinco anos (art. 12, II).

Há ainda as infrações administrativo-financeiras que dão ensejo à responsabilidade financeira, efetivada pelos Tribunais de Contas (CF, art. 71, VIII), no âmbito da sua função de controle, e pode consistir na obrigação de repor recursos públicos em caso de dano ao erário (responsabilidade financeira reintegratória) ou na de suportar as sançôes previstas em lei (responsabilidade financeira sancionatória), entre as quais está a multa. ${ }^{8}$

Como exemplo de modalidade sancionatória, a Lei Orgânica do TCU (Lei 8.443, de 1992) prevê, apenas para exemplificar, a aplicação de multas para as hipóteses de contas julgadas irregulares de que não resulte débito (art. 58, I), ato praticado com grave infração à norma legal ou regulamentar de natureza contábil, financeira, orçamentária, operacional e patrimonial (art. 58, II) e ato de gestão ilegitimo ou antieconômico de que resulte injustificado dano ao Erário (art. 58, III), entre outras.

Poderá ainda o TCU, nessas hipóteses, além da multa e demais penalidades administrativas, se considerar grave a infração cometida, por maioria absoluta de seus membros, declarar o responsável pelo ato inabilitado, por cinco a oito anos, para o exercício de cargo em comissão ou função de confiança no âmbito da Administração Pública (art. 60).

Ainda mais graves são os casos de crimes de responsabilidade, que dão ensejo ao impeachment, previstos na Lei 1.079, de 1950, e podem levar à perda do cargo e inabilitação para o exercício de função pública, entre os quais estão os atos do Presidente da República que atentarem contra a lei orçamentária e a guarda e o legal emprego dos dinheiros públicos.

Entre os crimes de responsabilidade contra a lei orçamentária, está o de "ordenar ou autorizar, em desacordo com a lei, a realização de operação de crédito com qual-

8 GOMES, Emerson C. S. Responsabilidade financeira - uma teoria sobre a responsabilidade no âmbito dos tribunais de contas. Op. cit., p. 35-43. 
quer um dos demais entes da Federação, inclusive suas entidades da administração indireta, ainda que na forma de novação, refinanciamento ou postergação de dívida contraída anteriormente" (art. 10, item 9), operaçôes que o TCU identificou como contrários à LRF, conforme visto anteriormente.

$\mathrm{E}$, entre as hipóteses de crime contra a guarda e o legal emprego dos dinheiros públicos, inclui-se a conduta de "contrair empréstimo, emitir moeda corrente ou apólices, ou efetuar operação de crédito sem autorização legal” (art. 11, item 3).

A multiplicidade das hipóteses para o enquadramento dos atos que contrariam a legislação financeira, envolvendo ilicitudes de natureza civil, penal e administrativa, cuja apuração e punição podem ocorrer a partir de diversos órgãos, sujeitando-se a procedimentos diversos, cada um a seu tempo e lugar, com princípios e regras próprios, não é o ideal, pois pode gerar conflitos de competência, duplicidade e superposição de sanções, exigindo um esforço dos operadores do Direito para a correta e adequada interpretação e aplicação da legislação. Um desafio aos estudiosos das diversas áreas do Direito envolvidas, especialmente o Direito Financeiro, que precisa ser vencido.

O fato é que não é por falta de leis que as "pedaladas fiscais" impedirão que se impute a responsabilidade e respectivas sanções aos gestores que as praticaram; a legislação é farta em punições para atos que atentam contra o bom uso dos recursos públicos, sejam elas de natureza civil, penal ou administrativa.

$\mathrm{O}$ que se pode concluir é que, independentemente das muitas possibilidades que a legislação oferece, o importante é reconhecer não ser mais possível tratar mal o dinheiro público e exigir que a legislação seja efetivamente aplicada com a punição dos responsáveis pelos atos que a contrariem a fim de que se tenha um ordenamento jurídico que se possa respeitar e no qual se possa confiar.

Ainda que as "pedaladas" possam não "dar cadeia", como expõe o título desta coluna, uma vez que, no âmbito da legislação penal, as sanções nela previstas tornam improvável uma condenação dos responsáveis a penas privativas de liberdade que se iniciem em regime fechado, podem ensejar fatos ainda mais graves, como o afastamento de um Presidente da República de seu cargo.

Que os gestores públicos aprendam a partir de agora que pedalar só é bom para os ciclistas! 
